\title{
DETERMINATION OF SOME TOTAL AND BIOAVAILABLE HEAVY METALS IN FARMLAND SOIL AROUND RIVERS NIGER AND BENUE IN LOKOJA, NIGERIA
}

\author{
Omoniyi ${ }^{1}$, K.I., Mukhtar, M. ${ }^{2 *}$ and Paul, E.D. ${ }^{1}$ \\ 1. Department of Chemistry, Ahmadu Bello University, Zaria, Nigeria. \\ 2. Department of Chemistry, Federal College of Education, Zaria, Nigeria. \\ *Correspondence author: almukh33@gmail.com
}

\begin{abstract}
The work assessed the distribution of $\mathrm{Cd}, \mathrm{Cu}, \mathrm{Mn}, \mathrm{Ni}, \mathrm{Pb}$ and $\mathrm{Zn}$ in the farmland soils around Rivers Niger and Benue and beyond the confluence in Lokoja, Nigeria. The samples were collected in the dry and rainy seasons of 2013 and 2014, digested with aqua regia and analysed for heavy metals using atomic absorption spectrophotometry. The soil pH ranged from 6.4 to 7.2 for the farmland

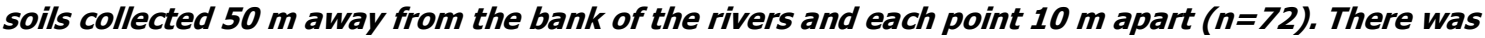
no significant difference in the mean values of the organic matter, organic carbon and moisture contents of the soils across the seasons. Cd concentration ( $\mathrm{mg} / \mathrm{kg}$ )in the soil samples collected in March 2013, June 2013, January 2014 and May 2014 at 0 - $15 \mathrm{~cm}$ depth ranged from 3.95 - 8.4; Cu 11.6 - 20.2; Mn 150.3 - 211.5; Ni 177.0 - 281.0; Pb 20.3 - 34.2 and Zn 40.5 - 77.8. The levels of the metals in the soil follow the ranking: $\mathrm{Ni}>\mathrm{Mn}>\mathrm{Zn}>\mathrm{Pb}>\mathrm{Cu}>\mathrm{Cd}$; with $\mathrm{Cd}$ and $\mathrm{Ni}$ being above European Union permissible limits. The order of the percentage of extracted metal by EDTA to the total metal content was $\mathrm{Pb}>\mathrm{Zn}>\mathrm{Cu}>\mathrm{Ni}>\mathrm{Mn}>\mathrm{Cd}$. I-geo pollution index showed that the farmland soils were moderately contaminated with Ni and Cd. Hence, there is the need to enforce environmental laws that borders on proper solid waste and effluent disposals.
\end{abstract}

Key Words: Heavy Metals- Pollution index - River Niger and Benue - Soils - Season

\section{INTRODUCTION}

About ninety natural elements exist in the environment and are distributed through the environment in the geochemical and bio-chemical cycles (Kaim and Schwederski, 1994). In recent years, with the development of global industrialization, both the type and content of heavy metals in the soil caused by human activities have gradually increased, resulting in the deterioration of the environment (Chao et al., 2014). Heavy metals are metallic chemical elements that have a relatively high density precisely greater than $5 \mathrm{gcm}^{-3}$. This classification includes transition metals and higher atomic weight metals of group IIIA to VA of the periodic table (Ademoroti, 1996). Some of these metals have been implicated for their toxic and hazardous effects (Ademoroti, 1996; Budnova et al., 1994).

As heavy metals get into the ecosystem they get enriched through the food chain. Once the soil accumulates heavy metal and is contaminated, it is difficult to get it remediated. In the past, soil contamination was not given the desired attention compared to air and water pollution, this is because soil contamination seldom happens and it is more difficult to control. However, in recent years soil contamination in developed countries has become an environmental concern worldwide due to its toxicity and accumulative behaviour (Purves, 1985; Omgbu, 1997; Ganogaiya et al., 2001; Chao et al., 2014).
The range and mean concentrations $(\mathrm{mg} / \mathrm{kg})$ of some heavy metals in the sediments collected from River Niger via Ajaokuta Steel Company, North Central, Nigeria between 2004 and 2005 were Zn 36.64 96.23 (70.70 \pm 10.68); Mn 4.97 to 21.77 (13.24 \pm 2.04); $\mathrm{Pb} 8.84$ to $17.52(12.35 \pm 1.14) ; \mathrm{Ni} 2.65$ to $18.61(9.67 \pm 2.91)$; $\mathrm{Cu} 0.89$ to $8.21(3.58 \pm 1.32)$; and $\mathrm{Cr} 0.48$ to $13.08(3.38 \pm 0.76)$ and $\mathrm{Cd} 0.07$ to 0.62 (0.27 \pm 0.07$)$ (Olatunde and Oladele, 2003).Thermal neutrons activation analysis technique (TNAA) indicated that some farmland soil in Lokoja contained $\mathrm{Mg}, \mathrm{K}, \mathrm{Ca}$ in large concentration; $\mathrm{Na}, \mathrm{Mn}$ and $\mathrm{V}$ were present in minor concentration in all the samples; $\mathrm{Al}$ and $\mathrm{Ti}$ were present in minor concentration while Dy was present in relatively low concentration (Oladipoet al.,2012).

Irrigation on river side soil of River Niger and Benue help to provide vegetable crops for the people of Lokoja and the environs during the dry season and early part of the rainy season; and also serves for rainy season farming. This study is aimed at assessing some heavy metals in farmland soils around Rivers Niger and Benue, following the flooding of 2012 in most parts along the rivers; the determination of the total $\mathrm{Cd}, \mathrm{Cu}, \mathrm{Mn}, \mathrm{Ni}, \mathrm{Pd}$ and $\mathrm{Zn}$ and the EDTAextractable amounts in the farmland soils collected beside River Niger, River Benue and beyond the confluence point, post-flooding becomes imperative. 
MATERIALS AND METHODS

Description of the Study Area and Sampling Sites

Lokoja, the capital of Kogi State, is located in the North Central geopolitical zone of Nigeria on $7^{0} 30^{\wedge} \mathrm{N}$ and $6^{\circ} 42^{\circ} \mathrm{E}$. It is the town where River Niger and River Benue meet. Niger River is the principal river of West Africa, extending about 4,180 km. Its drainage basin is $2,117,700 \mathrm{~km}^{2}$ in area. Its source is in the Guinea highlands in South eastern Guinea, it runs in a crescent through Mali, Niger, on the border with Benin and then through Nigeria meeting with River Benue. River Benue is the major tributary of the Niger River. The river is approximately 1,400 kilometres long. It rises in the Adamawa Plateau of Northern Cameroon, flows through Garoua and Lagdo Reservoir into Nigeria, south of the Mandara mountains, and through Jimeta, Ibi and Makurdi before meeting the Niger at Lokoja (Areola, 2004).

The soil samples were collected from bank of River Niger and River Benue and beyond the confluence point in Lokoja at a depth of $0-15 \mathrm{~cm}$ and distance $50 \mathrm{~m}$ away from the bank of the river with each point being $10 \mathrm{~m}$ away from the other.

\section{Collection of Soil Samples}

The river side soils for total metal determination were collected from the bank of River Niger (N1 - N6)and River Benue(B1- B6) and beyond the confluence point(CN1 - CN6, CB1 - CB6) at $0-15 \mathrm{~cm}$ depth in March 2013, June 2013, January 2014 and May 2014 using a stainless steel soil augar. As presented in Figure 1, the collection sites were $50 \mathrm{~m}$ away from the bank of the river and each point of collection was $10 \mathrm{~m}$ away from the other $(n=72)$.

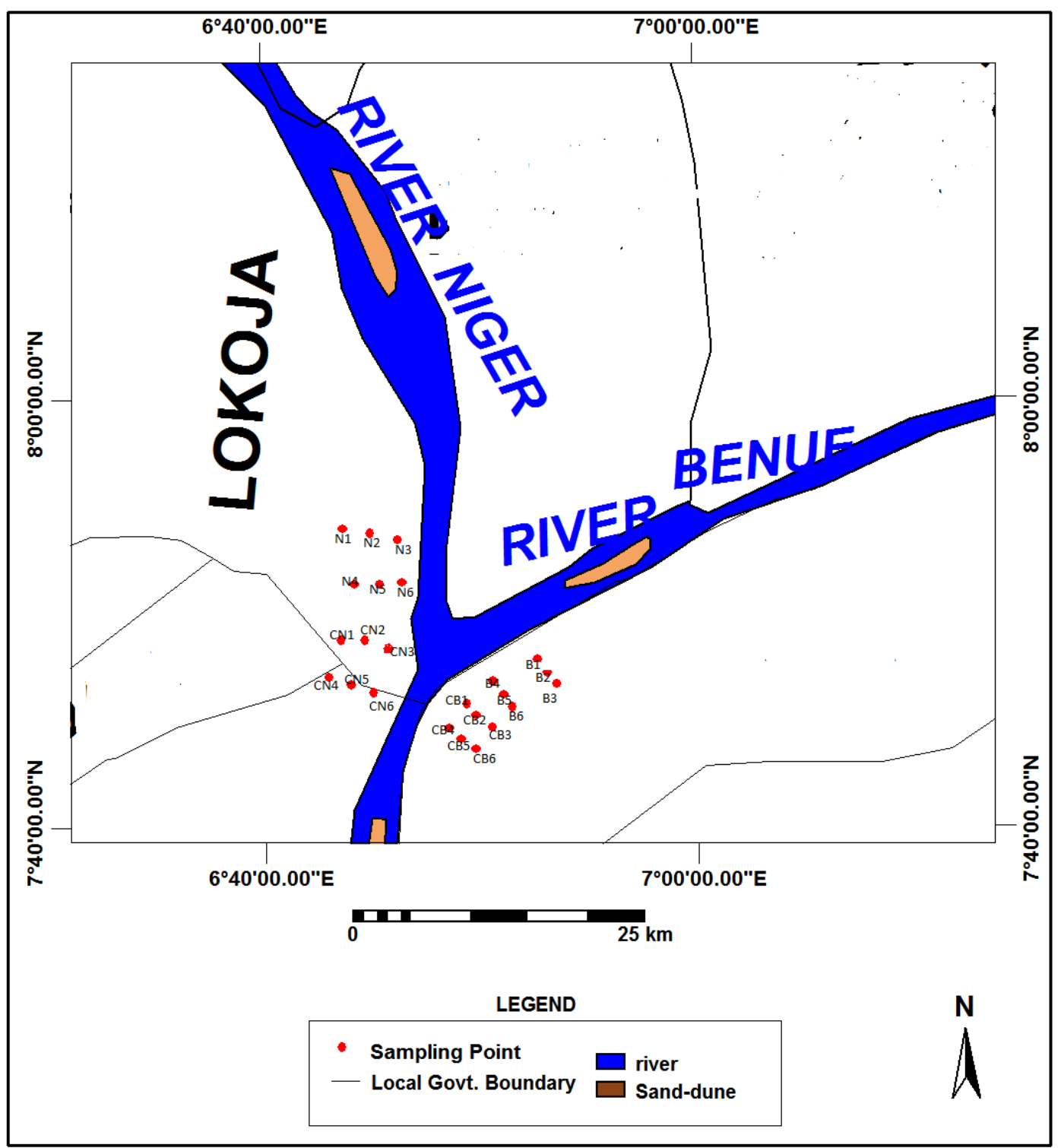

Key

Figure 1: Map Showing the Sampling Points

$N=R$. Niger riverside soil, $B=R$. Benue riverside soil, $C N=R$. Niger riverside soil after confluence, $C B=R$. Benue riverside soil after confluence 
BAJOPAS Volume 9 Number 2 December, 2016 Samples Pre - Treatment

Soil samples from each point was collected in triplicate and then homogenized in an agate mortar and pestle; each was then air-dried overnight in circulating air in an oven at $30^{\circ} \mathrm{C}$. It was then sieved through a $2 \mathrm{~mm}$ sieve (Onianwa et al., 2001).

Determination of the Soil Physico-chemical Properties

The soil $\mathrm{pH}$ in the suspension was determined using the method of Black (1965), textural class as adopted by Ogunfowakan (2009); organic carbon, organic matter and moisture contents were determined using the standard method adopted by Walkley and Black (1997).

\section{Digestion of Soil Samples}

In order to determine the total levels of $\mathrm{Cd}, \mathrm{Cu}, \mathrm{Mn}$, $\mathrm{Ni}, \mathrm{Pb}$ and $\mathrm{Zn}$, the method of Ogunfowokanet al. (2009) was employed. In which each $1.0 \mathrm{~g}$ amount of the sieved sample was digested using $30 \mathrm{~cm}^{3}$ aquaregia $\left(\mathrm{HCl}: \mathrm{HNO}_{3}, 3: 1\right)$, followed by $5 \mathrm{~cm}^{3} \mathrm{HF}$ after about $2 \mathrm{~h}$ of digestion. The levels of each element in $50 \mathrm{~cm}^{3}$ of the filtrate were determined using an atomic absorption spectrophotometer (model TAS990, Intec Co. Ltd., Rome); air acetylene flame was used, with the specific hollow cathode lamp required for each elemental determination at the Multi-user Laboratory of Ahmadu Bello University, Zaria, Nigeria. The quality assurance for the analyses was conducted through the spiking method, to evaluate the sample digestion process and effectiveness of the atomic absorption spectrophotometer (Uwumarongie and Okieimen, 2008; Lori et al., 2009; Amit et al., 2010).
Determination of the EDTA-Extractable Heavy Metals in the Soil Samples

In order to determine the phytoavailbale amounts of $\mathrm{Cd}, \mathrm{Cu}, \mathrm{Mn}, \mathrm{Ni}, \mathrm{Pd}$ and $\mathrm{Zn}$ in the farmland soil, the EDTA-extractableamount wasdetermined by putting $20 \mathrm{~g}$ of the sieved soil sample into twenty different $100 \mathrm{~cm}^{3}$ plastic bottles. Then $40 \mathrm{~cm}^{3}$ of $0.05 \mathrm{M}$ ethylenediaminetetraacetic acid (EDTA) solutions was added to each bottle and screw-capped tightly. The mixture was then shaken on a mechanical shaker at 120 r.p.m. for 2 h. The suspension was then filtered using a Whatmann no. 2 filter paper. The concentrations of the heavy metals were then determined using atomic absorption spectrophotometer (AAS), with the use of the appropriate standards in the EDTA matrix (Guptal and Mittal, 1981)

Determination oftheGeoaccumulation Indices (Igeo) for the soil samples

Geoaccumulation Index $\left(\mathrm{I}_{\text {geo }}\right)$ allows for the assessment of metal contamination through a comparison of the metal concentration in the contaminated soil with its concentration prior to contamination (Loska et al., 1997). Given as:

$$
\text { Igeo }=\log _{2}\left(\frac{C_{n}}{1.5 B n}\right)
$$

Where $\mathrm{Cn}$ is the measured mass fraction of the metal $\left(\mathrm{mg} / \mathrm{kg}^{-1}\right) . \mathrm{Bn}$ is the background mass fraction of the metal $\left(\mathrm{mg} / \mathrm{kg}^{-1}\right)$.

The Chinese Environmental Protection Administration (CEPA) environmental background value was used to calculate the Igeo in accordance to Wang et al. (2007). Muller's evaluation method (Muller, 1979) was used to evaluate the level of heavy metal contamination in the farmland soils collected from Lokoja in 2013 and 2014. The classification of the level of contamination is presented in Table 1.

Table 1: Classification of Geoaccumulation Index

\begin{tabular}{lcc}
\hline Geoaccumulation index & Classification & Level of contamination \\
\hline $5<$ I geo $\leq 10$ & 6 & Extremely serious \\
$4<$ I geo $\leq 5$ & 5 & Strong to extremely serious \\
$3<$ I geo $\leq 4$ & 4 & Strong \\
$2<$ I geo $\leq 3$ & 3 & Moderate to strong \\
$1<$ I geo $\leq 2$ & 2 & Moderate \\
$0<$ I geo $\leq 1$ & 1 & Light to moderate \\
I geo $\leq 0$ & 0 & Non contamination \\
\hline
\end{tabular}

\section{Statistical Analysis}

The variation in the levels of the metals accumulated in the soil with respect to the time of the year when the samples were collected was assessed using Analysis of Varience (ANOVA) at $\mathrm{P}<0.05$.

\section{RESULTS AND DISCUSSION}

Physicochemical Parameters of the Farmland Soils near River Niger, River Benue and Beyond Confluence Point

The physicochemical properties of the farmland soils in the dry and wet seasons of 2013 and 2014 are presented in Tables $2 \mathrm{a}-\mathrm{d}$. The soil $\mathrm{pH}$ ranged from 6.4 to 7.2 for the farmland soils of River Niger, River Benue and beyond the confluence in the dry season of 2013 (March 2013). The River Benue side (B) had the highest $\mathrm{pH}$ of 7.1 while the River Niger side $(\mathrm{N})$ had the least (6.7) (Table 2a). However, in the wet season of 2013 (June 2013), B had the highest (6.9) and the sample beyond confluence on River Niger side (CN) had the least (6.6) (Table 2b); however in the dry season of 2014 (January 2014) samples collected beyond the confluence on River Benue side (CB) had the highest $\mathrm{pH}$ of 7.2 and $\mathrm{N}$ had the least (6.5) (Table 2c). In the wet season of 2014 (May 2014), $\mathrm{N}$ had the highest (6.7) and CB the least (6.4) (Table 2d). The $\mathrm{pH}$ range obtained is close to $6.41-6.73$ obtained for some farmland soils of Lokoja by Oladipo et al. (2012). The $\mathrm{pH}$ values for the soil is suitable and could not facilitate solubility of the metals for bioavailability to plants (Oluyemi et al., 2008). 


\section{BAJOPAS Volume 9 Number 2 December, 2016}

The lowest organic matter content in the dry season of 2013 was recorded at $\mathrm{N}$ soil sample $\left(0.413 \mathrm{gkg}^{-1}\right)$ and the highest at $B\left(1.652 \mathrm{gkg}^{-1}\right.$ ) (Table 2a) while in the wet season of 2013 the organic matter content ranged from $0.406 \mathrm{gkg}^{-1}$ at $\mathrm{N}$ to $1.673 \mathrm{gkg}^{-1}$ at $\mathrm{B}$ (Table $2 \mathrm{~b}$ ). The highest organic matter content in the dry season of 2014 (January 2014) was in B (1.602 $\mathrm{gkg}^{-1}$ ) (Table 2c). On the other hand, in the wet season of 2014 organic matter ranged from $0.533 \mathrm{gkg}^{-}$

${ }^{1}$ at $\mathrm{N}$ to $1.859 \mathrm{gkg}^{-1}$ at $\mathrm{B}$. The higher organic matter contents of the farmland soil in the dry season compared to wet season could be due to the lower soil moisture contents during the dry season which enables microbial activities needed organic matter decomposition. The organic matter contents of soil plays an important role in absorption reaction in the soil, hence preventing pollutants from reaching ground water sources (Alloway, 1995).

Moisture content of the soil samples ranged from 64.1 to $85.4 \%$ (Table $2 \mathrm{a}$ to $2 \mathrm{~d}$ ), soil from $\mathrm{N}$ in the wet season of 2013 (June 2013) had the highest value $(85.4 \%)$ while the one from $\mathrm{CN}$ in the dry season (February 2013) had the least(64.1\%). There was no significant difference in the mean values of most of the parameters across the seasons.

Table 2a: Physicochemical Parameters and Heavy Metal Contents of Farmland Soil near River Niger and River Benue in the Dry Season of 2013 (March 2013)

\begin{tabular}{lllll}
\hline Soil property & $\begin{array}{l}\mathrm{N} \text { soil } \\
(\mathrm{mg} / \mathrm{kg})\end{array}$ & $\begin{array}{l}\text { B soil } \\
(\mathrm{mg} / \mathrm{kg})\end{array}$ & CNsoil $(\mathrm{mg} / \mathrm{kg})$ & CBsoil(mg/kg) \\
\hline $\mathrm{pH}$ & 6.7 & 7.1 & 6.9 & 6.9 \\
\% sand & 84 & 50 & 62 & 76 \\
\% clay & 6 & 34 & 26 & 10 \\
\%silt & 10 & 16 & 12 & 14 \\
Textural Class & Loamy sand & Sandy clay loam & Sandy loam & Sandy loam \\
Organic Carbon (\%) & 0.239 & 0.958 & 0.563 & 0.852 \\
Organic Matter $(\%)$ & 0.413 & 1.652 & 0.821 & 1.364 \\
Moisture Content(\%) & $78.20 \pm 0.01$ & $71.20 \pm 0.10$ & $64.10 \pm 0.12$ & $68.00 \pm 0.03$ \\
Total Cd (mg/kg) & $4.50 \pm 0.001$ & $4.15 \pm 0.001$ & $4.25 \pm 0.000$ & $3.95 \pm 0.001$ \\
Total Cu (mg/kg) & $18.80 \pm 0.000$ & $12.00 \pm 0.001$ & $17.20 \pm 0.000$ & $12.80 \pm 0.001$ \\
Total Mn (mg/kg) & $172.30 \pm 0.004$ & $176.20 \pm 0.004$ & $163.40 \pm 0.003$ & $150.30 \pm 0.003$ \\
Total Ni (mg/kg) & $187.50 \pm 0.001$ & $177.00 \pm 0.001$ & $187.50 \pm 0.001$ & $185.00 \pm 0.001$ \\
Total Pb $(\mathrm{mg} / \mathrm{kg})$ & $34.20 \pm 0.000$ & $29.00 \pm 0.000$ & $33.30 \pm 0.001$ & $21.10 \pm 0.000$ \\
Total $\mathrm{Zn}(\mathrm{mg} / \mathrm{kg})$ & $58.80 \pm 0.003$ & $50.70 \pm 0.001$ & $40.50 \pm 0.002$ & $44.50 \pm 0.003$ \\
\hline
\end{tabular}

$N=R$. Niger riverside soil, $B=R$. Benue riverside soil, $C N=R$. Niger riverside soil after confluence, $C B=R$. Benue riverside soil after confluence

\section{Levels of Total Heavy Metals in Farmland Soil Samples near R. Niger and Benue}

The total amounts of $\mathrm{Cd}, \mathrm{Cu}, \mathrm{Mn}, \mathrm{Ni}, \mathrm{Pd}$ and $\mathrm{Zn}$ in the farmland soils collected near River Niger,River Benue and beyond the confluence are presented in Table $2 \mathrm{a}-2 \mathrm{~d}$. The quality assurance carried out to determine the efficiency of the atomic absorption spectrophotometer through the spiking method revealed that the mean \% recovery for the analyses ranged from $82.9 \pm 0.15$ to $93.3 \pm 0.40 \mathrm{mg} / \mathrm{kg}$.

The highest concentration of $\mathrm{Cd}(8.4 \mathrm{mg} / \mathrm{kg})$ was obtained in both $B$ and $C B$ sampling sites in the wet season of 2014 (May 2014); while the least concentration $(3.95 \mathrm{mg} / \mathrm{kg})$ was obtained at $\mathrm{N}$ sampling site in the dry season of 2013 (March 2013), though this value was higher than the European Union Standards of $3 \mathrm{mg} / \mathrm{kg}$ for soil (EU, 2002). Cadmium is regarded as one of the most toxic trace elements in the environment; its intake in high doses is responsible for kidney failure, damage to testis and liver, softening and rotting of teeth and bones (a disease condition known as Itai-Itai) (Erickson et al., 1994; Prater, 1995; Alloway, 1995).

Table 2b: Physicochemical Parameters and Heavy Metal Contents of Farmland Soil near River Niger and River Benue in the Wet Season 2013 (June 2013)

\begin{tabular}{lllll}
\hline Soil property & $\begin{array}{l}\text { N soil } \\
(\mathrm{mg} / \mathrm{kg})\end{array}$ & $\begin{array}{l}\text { B soil } \\
(\mathrm{mg} / \mathrm{kg})\end{array}$ & CN soil $(\mathrm{mg} / \mathrm{kg})$ & $\begin{array}{l}\text { CB soil } \\
(\mathrm{mg} / \mathrm{kg})\end{array}$ \\
\hline $\mathrm{pH}$ & 6.7 & 6.9 & 6.6 & 6.7 \\
$\%$ sand & 84 & 50 & 62 & 76 \\
$\%$ clay & 6 & 34 & 26 & 10 \\
\%silt & 10 & 16 & 12 & 14 \\
Textural Class & Loamy sand & Sandy clay loam & Sandy loam & Sandy loam \\
Organic Carbon $(\%)$ & 0.278 & 0.935 & 0.547 & 0.825 \\
Organic Matter $(\%)$ & 0.406 & 1.673 & 0.839 & 1.350 \\
Moisture Content(\%) & $85.40 \pm 0.01$ & $77.3 \pm 0.10$ & $69.2 \pm 0.12$ & $73.3 \pm 0.03$ \\
Total Cd $(\mathrm{mg} / \mathrm{kg})$ & $5.60 \pm 0.001$ & $5.80 \pm 0.001$ & $5.80 \pm 0.001$ & $5.50 \pm 0.001$ \\
Total Cu $(\mathrm{mg} / \mathrm{kg})$ & $14.00 \pm 0.001$ & $17.20 \pm 0.001$ & $13.90 \pm 0.001$ & $15.00 \pm 0.001$ \\
Total $\mathrm{Mn}(\mathrm{mg} / \mathrm{kg})$ & $192.20 \pm 0.004$ & $181.30 \pm 0.004$ & $211.50 \pm 0.003$ & $150.30 \pm 0.003$ \\
Total $\mathrm{Ni}(\mathrm{mg} / \mathrm{kg})$ & $250.00 \pm 0.001$ & $218.70 \pm 0.001$ & $281.00 \pm 0.001$ & $250.00 \pm 0.001$ \\
Total Pb $(\mathrm{mg} / \mathrm{kg})$ & $26.50 \pm 0.000$ & $26.50 \pm 0.001$ & $20.30 \pm 0.001$ & $20.30 \pm 0.000$ \\
Total $\mathrm{Zn}(\mathrm{mg} / \mathrm{kg})$ & $66.20 \pm 0.003$ & $56.50 \pm 0.001$ & $61.60 \pm 0.001$ & $50.80 \pm 0.003$ \\
\hline
\end{tabular}




\section{BAJOPAS Volume 9 Number 2 December, 2016}

So awareness should be intensified on proper disposal of wastes. The level of $\mathrm{Cd}$ in the site could result from the use of phosphatic fertilizers, wastes from the sediments and the impact of the flooding of year 2012.
The range of $\mathrm{Cu}$ is $11.6 \mathrm{mgkg}^{-1}$ in the soil at $\mathrm{N}$ to 20.2 $\mathrm{mgkg}^{-1}$ in B both obtained in the wet season of 2014 . The amount of copper (Table 2a-d) were generally lower than the European Union Standards of 140 $\mathrm{mg} / \mathrm{kg}$ (EU, 2002). Thus, $\mathrm{Cu}$ is in amount that does not raise environmental concern.

Table 2c: Physicochemical Parameters and Heavy Metal Contents of Farmland Soil near River Niger and River Benue in the Dry Season 2014 (January 2014)

\begin{tabular}{lllll}
\hline Soil property & $\begin{array}{l}\text { N soil } \\
(\mathrm{mg} / \mathrm{kg})\end{array}$ & $\begin{array}{l}\text { B soil } \\
(\mathrm{mg} / \mathrm{kg})\end{array}$ & CN soil $(\mathrm{mg} / \mathrm{kg})$ & $\begin{array}{l}\text { CB soil } \\
(\mathrm{mg} / \mathrm{kg})\end{array}$ \\
\hline $\mathrm{pH}$ & 6.5 & 6.7 & 6.6 & 7.2 \\
$\%$ sand & 84 & 50 & 62 & 76 \\
\% clay & 6 & 34 & 26 & 10 \\
\%silt & 10 & 16 & 12 & 14 \\
Textural Class & Loamy sand & Sandy clay loam & Sandy loam & Sandy loam \\
Organic Carbon $(\%)$ & 0.239 & 0.958 & 0.563 & 0.852 \\
Organic Matter $(\%)$ & 0.473 & 1.602 & 0.721 & 1.263 \\
Moisture Content & $75.20 \pm 0.01$ & $73.20 \pm 0.10$ & $62.10 \pm 0.12$ & $67.20 \pm 0.03$ \\
Total Cd $(\mathrm{mg} / \mathrm{kg})$ & $5.80 \pm 0.001$ & $6.40 \pm 0.003$ & $6.40 \pm 0.000$ & $7.30 \pm 0.001$ \\
Total Cu $(\mathrm{mg} / \mathrm{kg})$ & $17.40 \pm 0.001$ & $20.00 \pm 0.001$ & $18.60 \pm 0.000$ & $17.50 \pm 0.001$ \\
Total $\mathrm{Mn}(\mathrm{mg} / \mathrm{kg})$ & $183.20 \pm 0.004$ & $187.70 \pm 0.004$ & $209.40 \pm 0.003$ & $208.20 \pm 0.003$ \\
Total Ni $(\mathrm{mg} / \mathrm{kg})$ & $223.00 \pm 0.001$ & $243.70 \pm 0.001$ & $209.40 \pm 0.001$ & $221.80 \pm 0.001$ \\
Total Pb $(\mathrm{mg} / \mathrm{kg})$ & $32.70 \pm 0.000$ & $23.50 \pm 0.000$ & $32.90 \pm 0.001$ & $30.50 \pm 0.000$ \\
Total $\mathrm{Zn}(\mathrm{mg} / \mathrm{kg})$ & $74.00 \pm 0.003$ & $60.20 \pm 0.001$ & $61.40 \pm 0.001$ & $62.50 \pm 0.003$ \\
\hline
\end{tabular}

$\mathrm{Mn}$ in the soil samples was generally higher than all the other metals studied; though the Mn contents recorded were generally lower than the European Union Standards of about $2000 \mathrm{mg} / \mathrm{kg}$ (EU, 2002). The Mn content was highest $\left(211.5 \mathrm{mgkg}^{-1}\right)$ in the soil at $\mathrm{CN}$ in the wet season of 2013 (June 2013) and lowest $\left(150.3 \mathrm{mgkg}^{-1}\right)$ at $\mathrm{CB}$ in both the dry and wet seasons of 2013. The observed large concentration of $\mathrm{Mn}$ in the soil samples might have been due to Table 2d: Physicochemical Parameters and Heavy Metal Contents of Farmland Soil near River Niger and River Benue in the Wet Season 2014 (May 2014)

\begin{tabular}{lllll}
\hline Soil property & $\begin{array}{l}\mathrm{N} \text { soil } \\
(\mathrm{mg} / \mathrm{kg})\end{array}$ & $\begin{array}{l}\text { B soil } \\
(\mathrm{mg} / \mathrm{kg})\end{array}$ & CN soil $(\mathrm{mg} / \mathrm{kg})$ & $\begin{array}{l}\text { CB soil } \\
(\mathrm{mg} / \mathrm{kg})\end{array}$ \\
\hline $\mathrm{pH}$ & 6.7 & 6.5 & 6.5 & 6.4 \\
\% sand & 84 & 50 & 62 & 76 \\
\% clay & 6 & 34 & 26 & 10 \\
\%silt & 10 & 16 & 12 & 14 \\
Textural Class & Loamy sand & Sandy clay loam & Sandy loam & Sandy loam \\
Organic Carbon $(\%)$ & 0.249 & 0.958 & 0.563 & 0.822 \\
Organic Matter $(\%)$ & 0.533 & 1.859 & 1.311 & 1.034 \\
Moisture Content & $81.20 \pm 0.01$ & $73.50 \pm 0.10$ & $68.10 \pm 0.12$ & $73.75 \pm 0.03$ \\
Total Cd $(\mathrm{mg} / \mathrm{kg})$ & $7.3 \pm 0.001$ & $8.4 \pm 0.001$ & $7.6 \pm 0.001$ & $8.4 \pm 0.001$ \\
Total $\mathrm{Cu}(\mathrm{mg} / \mathrm{kg})$ & $11.60 \pm 0.001$ & $20.20 \pm 0.001$ & $18.30 \pm 0.001$ & $18.00 \pm 0.001$ \\
Total $\mathrm{Mn}(\mathrm{mg} / \mathrm{kg})$ & $179.30 \pm .004$ & $205.20 \pm 0.004$ & $195.20 \pm 0.003$ & $171.00 \pm 0.003$ \\
Total $\mathrm{Ni}(\mathrm{mg} / \mathrm{kg})$ & $269.40 \pm 0.001$ & $267.40 \pm 0.001$ & $201.00 \pm 0.001$ & $220.80 \pm 0.001$ \\
Total $\mathrm{Pb}(\mathrm{mg} / \mathrm{kg})$ & $23.5 \pm 0.001$ & $33.4 \pm 0.001$ & $24.6 \pm 0.001$ & $28.1 \pm 0.001$ \\
Total $\mathrm{Zn}(\mathrm{mg} / \mathrm{kg})$ & $63.10 \pm 0.003$ & $77.80 \pm 0.001$ & $50.00 \pm 0.002$ & $51.60 \pm 0.003$ \\
\hline
\end{tabular}

Following from the results, $\mathrm{Ni}$ in the soil samples of the studied area of River Niger and River Benue was generally higher than the European Union Standards of $75 \mathrm{mg} / \mathrm{kg}$ (EU 2002). The level of $\mathrm{Ni}$ was highest $\left(281 \mathrm{mgkg}^{-1}\right)$ in the sample at CN in the wet season of 2013 (June 2013) and the lowest (177.0 $\mathrm{mgkg}^{-1}$ ) was in the soil obtained at the side of River (B) in the dry season of 2013 (March 2013). Nickel occurs naturally in soils as a result of the weathering of the parent background concentration of $\mathrm{Mn}$ in the soil and sediment of the rivers. The Mn content obtained for this study, however was generally lower than the 354 - $394 \mathrm{mgkg}^{-1}$ reported using neutron activation analysis for some farmland soils from Lokoja metropolis, Nigeria (Oladipo et al., 2012). Dara(1993) reported that manganese may be found in most soil since it is one of the key elements in the earth crust. 
BAJOPAS Volume 9 Number 2 December, 2016

Table 3: Permissible limits of heavy metals in soils

\begin{tabular}{lll}
\hline Elements & $\begin{array}{l}\text { *Threshold concentration in soil } \\
(\mathrm{EU}, 2002)(\mathrm{mg} / \mathrm{kg})\end{array}$ & **Background $(\mathrm{CEPA}, 1995)(\mathrm{mg} / \mathrm{kg})$ \\
\hline $\mathrm{Ni}$ & 75 & 26.9 \\
$\mathrm{Cu}$ & 140 & 22.6 \\
$\mathrm{Zn}$ & 300 & 74.2 \\
$\mathrm{~Pb}$ & 300 & 26 \\
$\mathrm{Cd}$ & 3 & 0.097 \\
$\mathrm{Mn}$ & 2000 & 63.2 \\
\hline
\end{tabular}

The concentrations of $\mathrm{Pb}$ in the soil samples were generally low compared to the European Union Standards of about $300 \mathrm{mg} / \mathrm{kg}$ (EU, 2002). The concentrations of $\mathrm{Pb}$ obtained were generally within the limits for agricultural soils.

The amount of $\mathrm{Zn}$ in the soils showed that the soil samples in CN during the dry season of 2013 (40.5 $\mathrm{mgkg}^{-1}$ ) was the lowest while the sample from B in the wet season of $2014\left(77.8 \mathrm{mgkg}^{-1}\right)$ had the highest $\mathrm{Zn}$ concentration. The $\mathrm{Zn}$ concentrations in the studied area of River Niger, Benue and beyond the confluence point were lower than the European Union Standards of $300 \mathrm{mg} / \mathrm{kg}$. This might be due to the continuous removal of heavy metals by the food crops grown in this area and also due to leaching of heavy metals into the deeper layer of the soil and to the ground water. $\mathrm{Zn}$ is released to the environment from both natural and anthropogenic sources; however the releases from anthropogenic sources (smelter slags and wastes, mine tailings, coal and bottom fly ash, fertilizers) are greater than those from natural sources. Although zinc usually remains adsorbed to soil, leaching has been reported (Prater, 1995; Omgbu, 1997).

The levels of the metals studied in the farmland soils follow the ranking $\mathrm{Ni}>\mathrm{Mn}>\mathrm{Zn}>\mathrm{Pb}>\mathrm{Cu}>\mathrm{Cd}$. The levels of $\mathrm{Cd}, \mathrm{Cu}$ and $\mathrm{Mn}$ in the soils collected around River Benue side were significantly elevated compared to the soil samples around River Niger (ANOVA at P < 0.05 ).

\section{Geoaccumulation index (Igeo) of the Farmland Soils from River Niger andRiver Benue in Lokoja}

The calculations of Igeo values for $\mathrm{Cd}, \mathrm{Cu}, \mathrm{Ni}, \mathrm{Mn}, \mathrm{Pb}$ and $\mathrm{Zn}$ were carried out and referenced to Table 1. The Igeo values for $\mathrm{Ni}$ in all the sampling sites were greater 1 but less than 2 (indicating light to moderate contamination). The Igeo values obtained for $\mathrm{Cd}$ are greater than 2 , this varied with the range 2.163 2.649 , indicating moderate to strong contamination.
Geoaccumulation index showed that $\mathrm{Cd}$ and $\mathrm{Ni}$ were the major pollutant of the farmland soil near River Niger, Benue and beyond the confluence point in Lokoja, Nigeria. Cadmium virtually polluted all the riverside soils, thus having the highest Igeo in the wet season of 2014 (Igeo $=2.649$ ) and lowest in the dry season of 2013 (Igeo $=2.163$ ). This could be attributed to the possibility of the transportation of $\mathrm{Cd}$ containing deposits like phosphatic fertilizers by water run off to the surrounding soil and the discharge of $\mathrm{Cd}$ containing effluents into the rivers.

Igeo for $\mathrm{Mn}$ was generally above zero in all the riverside soils and across the seasons, an indication of $\mathrm{Mn}$ pollution in most of the sites. The highest Igeo value obtained for Mn was in wet season 2013 (Igeo $=1.157$ ) at $\mathrm{CN}$, which showed a relative pollution by $\mathrm{Mn}$, while it was lowest (Igeo $=0.678)$ at site $C B$ in both the dry and wet season of 2013. These values indicated moderate pollution. However, $\mathrm{Cu}, \mathrm{Zn}$ and Pbdid not pollute the riverside soils even across the seasons; this could be accounted for by the nature of the solid wastes deposited into the rivers upstream, as there are different kinds of activities around River Niger and River Benue from the source to the different water courses.

The Igeo values indicated that $\mathrm{Cu}, \mathrm{Zn}$ and $\mathrm{Pb}$ were in class 0 (uncontaminated); $M n$ is in class 1 (except for the soil samples collected from $\mathrm{CN}$ in the wet season of 2013 and both the dry and wet season in 2014 that had the Igeo $>1$ ) for all the riverside soils. This indicated that the soil in these riverside are uncontaminated to moderate contamination by $\mathrm{Cu}$, $\mathrm{Mn}, \mathrm{Pb}$ and $\mathrm{Zn}$. Heavy metals extracted by EDTA should be the fraction available for plants. Hence, the amounts of the heavy metals recorded in Table 4 were significantly lower than the total amounts in the soils (Table 2 a-d).

The ranking of the amount of the EDTA extractable metals is the same as obtained for the total metal content.

Table 4: Mean concentration of the EDTA Extractable Fraction of the Heavy Metals in the Riverside Soils of River Niger and River Benue

\begin{tabular}{cllllll}
\hline Metal & $\begin{array}{l}\mathrm{N} \\
(\mathrm{mg} / \mathrm{kg})\end{array}$ & $\begin{array}{l}\mathrm{B} \\
(\mathrm{mg} / \mathrm{kg})\end{array}$ & $\begin{array}{l}\mathrm{CN} \\
(\mathrm{mg} / \mathrm{kg})\end{array}$ & $\begin{array}{l}\mathrm{CB} \\
(\mathrm{mg} / \mathrm{kg})\end{array}$ & $\begin{array}{l}\text { Control } \\
(\mathrm{mg} / \mathrm{kg})\end{array}$ & \% total content \\
\hline $\mathrm{Cd}$ & $1.20 \pm 0.001$ & $1.70 \pm 0.001$ & $1.40 \pm 0.001$ & $1.50 \pm 0.001$ & $0.92 \pm 0.001$ & 15.0 \\
$\mathrm{Cu}$ & $4.70 \pm 0.001$ & $7.00 \pm 0.001$ & $4.20 \pm 0.001$ & $5.20 \pm 0.002$ & $8.30 \pm 0.001$ & 31.2 \\
$\mathrm{Mn}$ & $45.00 \pm 0.004$ & $38.80 \pm 0.002$ & $40.60 \pm 0.004$ & $37.70 \pm 0.007$ & $58.00 \pm 0.010$ & 21.5 \\
$\mathrm{Ni}$ & $41.00 \pm 0.001$ & $67.00 \pm 0.001$ & $64.00 \pm 0.001$ & $60.00 \pm 0.001$ & $22.30 \pm 0.001$ & 24.2 \\
$\mathrm{~Pb}$ & $12.90 \pm 0.001$ & $18.70 \pm 0.001$ & $14.50 \pm 0.001$ & $18.30 \pm 0.001$ & $11.20 \pm 0.001$ & 58.7 \\
$\mathrm{Zn}$ & $20.40 \pm 0.003$ & $21.30 \pm 0.004$ & $24.90 \pm 0.003$ & $22.20 \pm 0.005$ & $24.70 \pm 0.004$ & 36.4 \\
\hline
\end{tabular}


The percentage of the phytoavailable concentrations of the metals to the total amounts of the metals in the soil samples differ among the elements: lead hadthe highest extractable relative amount $(58.7 \%)$, followed by zinc $(36.4 \%)$, copper (31.2\%) nickel $(24.2 \%)$, manganese $(21.5 \%)$ and the least was for cadmium $(15.0 \%)$ (Figure 2). However, lead had the extractable absolute amounts (18.70 \pm 0.001 $12.90 \pm 0.001 \mathrm{mg} / \mathrm{kg}$ ), and cadmium $1.20 \pm 0.001$ $1.70 \pm 0.001 \mathrm{mg} / \mathrm{kg}$.Similar results were reported for the EDTA extraction in a farmland soil in Croatia, (Lončarić et al. 2008) with lead, copper and zinc recording higher percentage extractability than for nickel, cadmium and least for $\mathrm{Mn}$.

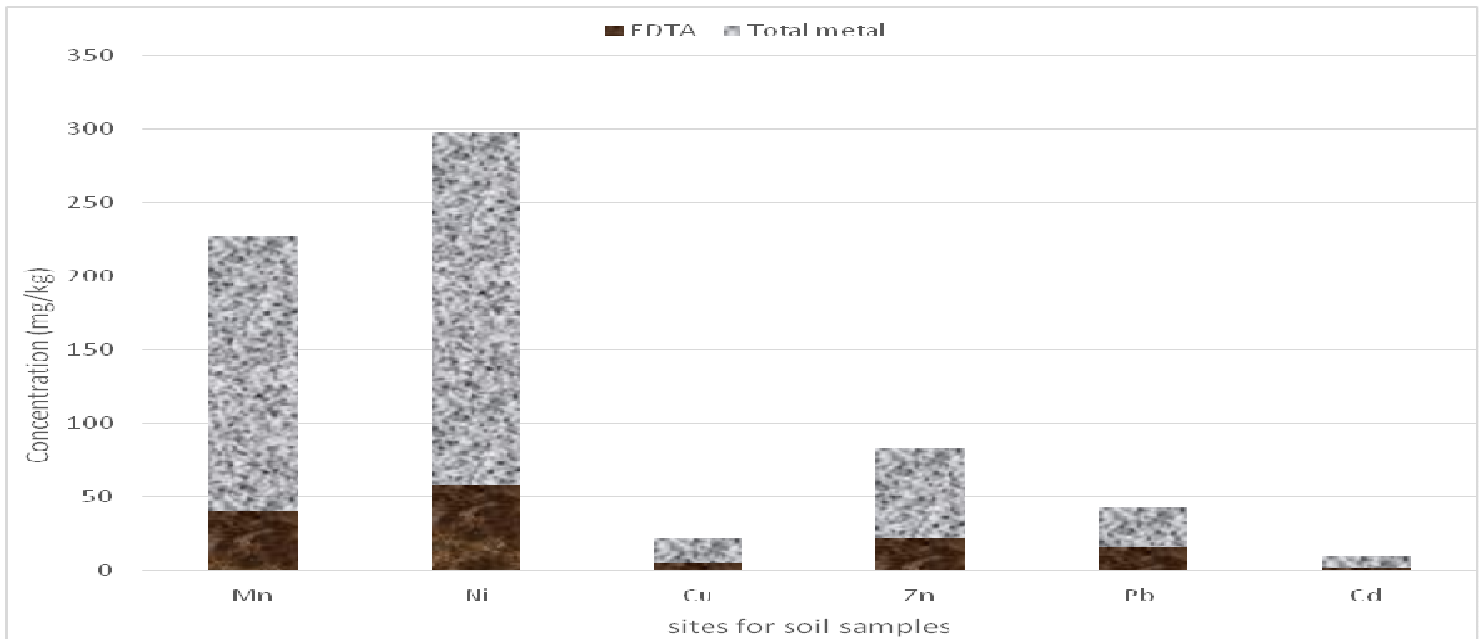

Figure 2: EDTA-Extractable Concentration of the Heavy Metals in Soil versus the Total Metal Content in the Riverside Soils of River Niger and River Benue

\section{CONCLUSION}

Almost all the soil samples were found to be enriched with the selected heavy metals but in all the samples the concentrations of nickel and cadmium were in levels above the permissible limits. The heavy metal that recorded the highest total content in the agricultural soils was nickel, followed by manganese, zinc, lead, copper and then cadmium regardless of the soil $\mathrm{pH}$. The order of the amount of the EDTA-extracted metals was almost the same with that of total metal, but the percentage of the metal extracted by EDTA to the total metal content was in a different order: $\mathrm{Pb}>\mathrm{Zn}>\mathrm{Cu}>\mathrm{Ni}>\mathrm{Mn}>\mathrm{Cd}$. The I-geo pollution index showed that the farmland soils located near River Niger, River Benue and beyond the confluence point in Lokoja, Nigeria are not contaminated and for some cases are moderately contaminated with the studied metals (I-geo grade 0 and grade 1 ). This suggests that the riverside soils are having background concentrations for $\mathrm{Cu}, \mathrm{Zn}, \mathrm{Pb}$ and $\mathrm{Mn}$ and these elements are practically unchanged by anthropogenic influences, while the concentration of $\mathrm{Ni}$ and $\mathrm{Cd}$ exceeded the average shale value.

\section{REFERENCES}

Ademoroti, C.M.A. (1996), Environmental Chemistry and Toxicology. Foludex press Ltd, Ibadan.

Alloway, B. J and Ayres, D. C. (1997). Chemical principles of environmental pollution. Blackie Academy and Professional, P. 353-359.

Alloway, B. J. (1995). Cadmium. In: Heavy metals in soils (2nd edn.) (ed. B.J. Alloway). London: Blackie Academic \& Professional.

Amit, S.C., Rekha, B., Atul, K.S., Sharad S.L. and Dinesh, K. (2010).Determination of lead and cadmium

\section{RECOMMENDATIONS}

It is recommended that research be carried out regularly to ascertain the level of pollution of heavy metals in the farmland soils near River Niger and River Benue. Also, the study of heavy metals in the farmland soils near River Niger and River Benue should be carried out at varying depths. The bioaccumulation of the studied metals by leafy vegetables should be carried out.

In conclusion, there should be enforcement of environmental laws that will minimise the discharge of untreated wastewater to water bodies. Likewise the disposal of wastes into rivers should be avoided to mitigate against flooding.

\section{ACKNOWLEDGEMENT}

I want to express my profound gratitude to my supervisors, Dr. K. I. Omoniyi and Dr. E. D. Paul for their guidance, instruction and constructive criticism all through the period of this research.

\section{CONFLICTS OF INTEREST}

The authors have noconflict of interest.

in cosmetic products. Journal of Chemical and Pharmaceutical Research, 2(6): 92- 97.

Areola, M. A. (2004). Monitoring ground water quality for small-scale irrigation: A study of southwest Sokoto-Rima, Nigeria. Agricultural Engineering International: The CIGR e-journal, (7): 4-8.

ATSDR, (2008). Draft toxicological profile for cadmium Atlanta: US Department of Health and Human Services, Agency for Toxic Substances and Disease Registry. Available from: http://www.atsdr.cdc.gov/toxprofiles/tp5-p.pdf . Accessed June 2009. 
BAJOPAS Volume 9 Number 2 December, 2016

Black, C.A. (1965). Methods of soil analysis. America Society of Agronomy. Edited: J. Madison, Wisconsin U.S.A.1-19.

Budnova, T.K., Gergora, K.M., Petrov, M.V. and Minka, V.N. (1994). Removal of metal ion from aqueous solution by activated Carbon obtained from different raw material. Journal of Chemical Technology and Biotechnology. 60:179 - 180.

CEPA (Chinese Environmental Protection Administration), (1990). Elemental background values of soils in China. Environmental Science Press of China, Beijing, China

CEPA (Chinese Environmental Protection Administration). (1995). Environmental Quality Standard for Soils (GB15618-1995). Environmental Science Press of China, Beijing, China

Chao, S., LiQin, J. and WenJun, Z. (2014). A review on heavy metal contamination in the soil worldwide: Situation, impact and remediation techniques. Environmental Skeptics and Critics, 3(2): 24-38.

Dara, S.S. (1993). A text of environmental chemistry and pollution control. S. Chand and Company Ltd. Ram Nagar, New Delhi, 110055.

ECB, (2007). European Union Risk Assessment Report. Cadmium oxide and cadmium metal, Part 1 environment. Volume 72. EUR 22919EN. Luxembourg: Office for Official Publications of the European Communities. Available from: http://ecb.jrc.ec.europa.eu/documents/ExistingCh emicals/RISK_ASSESSMENT/REPORT/cdmetal_cdo xideENVreport302.pdf. Accessed June 2009].

Erickson, M.M., Pokis-Dickson, A. W. and Hilliman, L.S. (1994) Tissue mineral levels in victims of sudden infant death syndrome I. Toxic metals, lead and cadmium, Pediatric Research,17: 779 - 784.

European Union, (2002). Heavy Metals in Wastes, European Commission on Environment. http://ec.europa.eu/environment/waste/studies/p df/ heavymetalsreport.pdf. Accessed june 2015.

Ganogaiya, T. R., Tabudravo, R. and Suth, S. ( 2001). Heavy metal contamination of Lami Coastal environment. Fiji Southern Pacific. Journal of Natural Science, 19: 24 - 29.

Gupta, V. K., and S. B. Mittal. 1981. Evaluation of chemical methods for estimating available $\mathrm{Zn}$ and response of green gram (phaseolus Aureus Roxb) to applied $\mathrm{Zn}$ in non-calcareous soils. Plant and soil. 63 (3): 477-484.

Kaim, W. and Schwederski, B. (1994). Bioinorganic chemistry: Inorganic elements in the chemistry of life. wiley, Chichester, U.K. P. $359-361$.

Lončarić, Z., Karalić, K., Popović, B., Rastija, D., Vukobratović, M. (2008). Total and plant available micronutrients in acidic and calcareous soils in Croatia. Cereal Research Communications,36: 331-334.

Lori, A.J., Omoniyi, K.I. and Ekanem, J.E. (2009).Comparative evaluation of metal ions release from titanium and Ti-Al6-Nb7 into biofluids, Dental Research Journal, 6(1): 7-11.

Loska, K., Cebula, J., Pelczar, J., Wiechula, D. and Kwapulinski, J. (1997). Use of enrichment and contamination factors together with geoaccumulation indices to evaluate the content of $\mathrm{Cd}, \mathrm{Cu}$ and $\mathrm{Ni}$ in the Rybnik water reservoir in Poland. Journal of Air and Soil Pollution,93: 347365.
McGrath, S. P. (1995). Nickel. In Heavy Metals in Soils (2nd edn.) (ed. B.J. Alloway). London: Blackie Academic \& Professional.

Muller, G. (1979). Schwermetalle in den sedimenten des Rheins-veranderungen seit, Umschall, 79, P. 778783.

Ogunfowakan, A.O., Oyekunle, J. A.O., Dorosinmi, L.M., Akinjokun, A.I and Gabriel, O.D. (2009). Speciation study of lead and manganese in roadside dusts from major roads in Ile-Ife, South Western Nigeria. Journal of Chemistry and Ecology, 25(6): 405-415.

Oladipo, M.O.A., Njinga, R.L., Achi, S.S., Ogunleye, P.O., Alfa, B. and Ibrahim, A.A. (2012). Analysis of savannah and rainforest soils of Nigeria using thermal neutron activation analysis technique. International Journal of Science and Technology, 2(8): 583 - 589.

Olatunde S. O. and Oladele O. (2003). Eco-partitioning and indices of heavy metal accumulation in sediment and Tilapia zillii fish in water catchment of River Niger at Ajaokuta, North Central Nigeria. International Journal of Physical Sciences, 8(20), 1111-1117.

Oluyemi, E.A., Feuyit, G., Oyekunle, J.A.O and Ogunfowokan, A.O. (2008). Seasonal variations in heavy metal concentrations in soil and some selected crops at a landfill in Nigeria. African Journal of Environmental Science and Technology, 2(5): 89-96.

Omgbu, J.A. (1997). The distribution of $\mathrm{Fe}, \mathrm{Hg}, \mathrm{Zn}, \mathrm{Cd}$, $\mathrm{Cu}$ and $\mathrm{Pb}$ in soil of Forcados terminal and its environs. M.Sc. Thesis, Department of Chemistry, University of Port Harcourt, Nigeria.

Onianwa, P.C., Jaiyeola, O.M. and Ege, R.N.K. (2001) Heavy metals contamination of top soil in the vicinities of auto-repair Workshops, gas and station and motor parks in Nigerian cities. Toxicology and Environmental Chemistry, 84 (1-4): 33-39.

Page, A.L., Chang, A.C. and EL-Amamy, M. (1987). Cadmium Levels in Soils and Crops in the United States (Chapter 10). Dept.of Soil and Environmental Sciences, University of California, Riverside, CA 92521

Prater, J.C. (1995) Environmental Contaminant reference Databook vol. IVan Nostrand Reinhold, New York.

Purves, D. (1985). Trace element contamination of the enviromment. Amstardam Bibovior. P. 45.

Uwumarongie, E.G. and Okieimen, F. E. (2008).Prediction of arsenic, chromium and copper availability to maize seedling in contaminated soil. Proceeding of the Chemical Society of Nigeria Delta 2008 Conference, 341- 348.

Walkley, A., Black, I.A. (1997). An examination of the detjare method for determining soil organic matter and a proposed modification of the chronic acid titration. Soil Science Journal, 37: 29- 36.

Wang, D.D., Li, H.X., Hu, F.G. (2007). Role of earthworm-straw interactions on phytoremediation of $\mathrm{Cu}$ contaminated soil by ryegrass. Acta Ecologica Sinica, 27(4): 12921299.

Wood, J.M. (1974). Biological cycles for toxic elements in the environment. Science, 183: 1049-1052. 